\title{
Meanings of Objektive und Subjektive Constructions in German Sentences and Their Equivalences in Indonesian
}

\author{
Sulis Triyono \\ Yogyakarta State University \\ E-mail: sulis@uny.ac.id
}

\begin{abstract}
This study aims to describe: (1) objektive und subjektive constructions in German sentences, (2) meanings of objektive und subjektive in German sentences, and (3) equivalences of objektive und subjektive in German sentences in Indonesian. This was a qualitative descriptive study. The objects of the research data were lingual units of modality constructions with objective and subjective meanings in both German phrases and sentences. The subjects of the data were modal verbs in German sentences. The data sources were the magazine NADI Indonesia Deutsch Edisi I/ No. 16 Tahun 2012, Edisi I/No. 17 Tahun 2013, and Edisi II/No. 18 Tahun 2013. The data were collected by means of reading and noting techniques and analyzed by means of the translational, equivalent, and distributional techniques. The data validity was assessed through the semantic validity and the inter-rater and intra-rater techniques. The research findings are as follows. (1) the objektive construction in German is S - Inf+Modalverb and the subjektive construction is S+Inf Modalverb. (2) Meanings of objektive are those which are loose in nature because because lexical elements of modality can reveal utterance contents while meanings of subjektive are those outside lexical elements because they are affected by speakers' subjective intentions. (3) The equivalences of objektive und subjektive in German sentences in Indonesian are in the form können appearing 107 times, equivalent to meanings of dapat, bisa, ada, menjadi, berhasil, mampu, meraih, terdiri, sungguh, and makna zero. Dürfen (8) are equivalent to meanings of dapat, boleh, and makna zero. Modalverb sollen (27) are equivalent to meanings of harus, akan, bisa, seharusnya, perlu, dan makna zero. Wollen (3) are equivalent to meanings of ingin, terus terang, and makna zero. Müssen (31) are equivalent to meanings of harus, dapat, bisa, and makna zero. Möchten (16) are equivalent to meanings of ingin, berminat, perlu, and makna zero.
\end{abstract}

Keywords: meanings of objektive und subjektive, German sentences, comparative research

\section{INTRODUCTION}

What is called Modalverb 'modal verb or verb of modality' in German sentences is used to express a feeling of the speaker's. The expression of the speaker's feeling, or attitude, to a fellow speaker by using a modal verb has two possible types of meaning, namely, objective meaning and subjective meaning. The meaning which is objective in nature is found inside the modal verb as lexical item while the meaning which is subjective in nature is found outside it as lexical item. A word is often interpreted subjectively according to the speaker's wish in making an utterance to express his or her intention, as in the case taken for example as follows. 
(1) Er will mich anrufen.

(Helbig/Buscha, 2005: 121)

(2) Er will mich angerufen haben.

(Helbig/Buscha, 2005: 121)

In Sentence (1) above, Er will mich anrufen., the meaning is objective in nature because the construction involving its modal verb is in the Präsens 'present' form of sentence. In addition, the semantic meaning of the sentence largely depends on the lexical items in the construction involving the modal verb will plus the verb anrufen. The modal verb will means 'will' (the one indicating future action, that is) while the verb anrufen means 'call by phone'. So will anrufen means 'will call by phone'. Sentence (1) above means 'He will call me (by phone, that is) ' or 'He will phone me'. The modal verb will meaning 'will' as above functions as indicator of modality in German sentences. That sentence has the role of expressing modality with objective meaning. It is indicated by two factors, first, the presence of will as Modalverb (or modal verb or verb indicating modality) and, second, the presence of the verb anrufen. When considered based on the meaning found in the German sentence, it would be seen that the sentence has a modal verb with objective meaning. It is caused by the presence of the semantic meaning found in the lexical item will which, as Modalverb or verb indicating modality, also functions as Hilfsverb 'helping verb' and the verb anrufen meaning 'call by phone' as Hauptverb 'main verb' in the sentence. In other words, there is a close relation in meaning between the two words being respectively a modal verb and a verb in the infinitive and their being lexical items.

Sentence (2) above, Er will mich angerufen haben., contains the verb will indicating modality and the verb sequence angerufen haben. The modal verb will means 'will' as in sentence (1) and the verb phrase angerufen haben means "have phoned'. In Sentence (2), the verb will indicates modality and is, therefore, among the verbs functioning as Hilfsverb 'helping verb' and the verb phrase angerufen haben contains, or, rather, begins with the verb functioning as Hauptsverb 'main verb'. Though the verb will as Modalverb "verb indicating modality' functions "merely" as Hilfsverb 'helping verb' in the sentence, it plays an important part in determining the meaning of the sentence on the whole. It is caused by the presence of an important factor that could determine whether the lexical meaning of a modal verb is eventually objektive Bedeutung 'objective meaning' or subjektive Bedeutung 'subjective meaning' in German sentences.

According to the indicators found in Sentence (2) above, it could be said that the modal verb has subjective meaning. It is caused by the presence of the construction of the verb will indicating modality followed by the main verb beginning the verb phrase angerufen haben making the sentence fall into the category of Futur II. A sentence of Futur II is a sentence having a figurative meaning. The meaning of the modal verb and the main verb phrase in Sentence (2) above is more of estimation, assumption, or uncertainty. So the modal verb in that sentence has a subjective meaning because some element outside it as lexical item is highly influential in determining the sentence meaning. After closer examination on Sentences (1) and (2) above, it could be said that both have lexical items that are respectively modal verbs and main verbs. The difference is that Sentence (1) has objective meaning while Sentence (2) has subjective meaning.

Therefore, it could be concluded that the meaning that is objective in nature is that found in a word as lexical item while the one subjective in nature is that outside it as lexical item, namely, the meaning influenced by the speaker's intention in making the utterance concerned. Take, for example, the sentence as follows:

Ich kann schwimmen 'I can swim'.

The sense of can swim in the sentence depends very much on the speaker. There is a possibility that, compared to someone who is better in swimming, the speaker could not yet be said to be already able to swim. The meaning of can swim is determined by one's intention in making the utterance concerned. Thus, the meaning which is external to the lexical item is the one not determined by the lingual element used by the speaker concerned and depends very much on the speaker's intention.

The subjective meaning appears when the speaker wishes to express an attitude associated to a meaning outside the lexical context being 
used. It is related to the semantic meaning in the utterance context referring to other meaning covering (1) Vermutungsbedeutung 'assumptive meaning' of such expressions as perhaps, don't know, and not clear; and (2) Bedeutung einer fremden Behauptung 'strange-statement meaning' commonly used to express a message delivered by the speaker concerned to a hearer which contains something outside the grammatical or lexical context. In other words, the message contains a meaning external to modality and very subjective in nature depending on the intention and purpose of the speaker concerned in expressing what is in his or her mind by making the particular utterance of his or hers.

This use of modality with objective and subjective meanings is found in all languages, not excluding the Indonesian language. In Indonesian, such words as mau/ akan/hendak 'will', harus 'must', and boleh 'may (of permission)' are modal verbs with objective meaning while the words with subjective meaning could be, among others, mungkin 'perhaps', kayaknya 'seemingly', acapkali 'often', and barangkali 'maybe'. In the Indonesian language, the expression of a speaker's attitude is commonly actualized in accordance with the explicit word meaning. It does not remove the possibility of it appearing at the grammatical level, as in its use in such Indonesian sentences as Diminum (esnya)! 'Drink (the ice)!' and Dimakan (kuenya)! 'Eat (the cake)!' Each Indonesian word between parentheses is the one not uttered by the speaker concerned. However, in the context of the conversation the objects called es and kue are available near the hearer so that the person addressed already understands the speaker's intention though the speaker does not mention the objects concerned by saying the words es and $k u e$. Therefore, the grammatical element related to the context of the conversation is already implied. Verhaar (2002: 13) states that semantic description is the lexicography of which each lexeme is given what he calls perian or meaning description which is then semantic in nature. While the meaning description fitting the lexicography then implies objective meaning, semantic meaning description implies subjective meaning. It is a problem for non-native speakers who do not understand enough the modality construction in Indonesian to comprehend the context of objective and subjective meaning in Indonesian sentences. Vice versa, it would become a problem and a difficult matter to understand for Indonesian speakers who are students at the Department of German Language Education, Faculty of Languages and Arts, State University of Yogyakarta, and still in the process of studying German if they do not understand such modality construction of the language that they are studying as that in the following data example.

(3) Sie dürften schon schlafen. (Helbig/Buscha, 2005: 121)

Sentence (3) above could be interpreted to mean 'You may sleep' if linked to the modality function in sentences which has objective meaning. In actuality, however, the sentence is subjective in meaning. It is why it is difficult enough for the students to understand the modality function in a German sentence if they do not correctly understand the intention and purpose of expressing the attitude found in the sentence. Sentence (3) above means 'Perhaps you have slept'. The word perhaps appears in result of the presence of subjective meaning. As previously mentioned, subjective meaning could be interpreted as meaning that appears outside lexical meaning. A lexical item in German such as the word wahrscheinlich or vielleicht would be considered equivalent to that in Indonesian such as the word mungkin 'perhaps' or the phrase bisa jadi 'probably' so that the German sentence Sie dürften schon schlafen is equivalent to the Indonesian sentence Mungkin anda sudah tidur 'Perhaps you have slept' or Bisa jadi, anda sudah tidur 'Probably you have slept'.

In German, what could be called modal expressions are of two kinds, namely, Modalwort and Modalverb. Modalwort is such a word as vermutlich 'seemingly' and wahrscheinlixch 'perhaps' in, for example, the following sentences:

Er kommt vermutlich 'He may come'.

Er kommt wahrscheinlich 'He may come'.

As for Modalverb, it is such a modal verb as müssen 'must', sollen 'shall', and können 'can', used as that in the sentence as follows:

Er mußt heute kommen 'He must come now'

Based on the problem exposition above, an in-depth study is needed concerning modality construction with objective and subjective 
meaning in German sentences and its equivalent in Indonesian. It is in order that students who are in the process of learning German as a foreign language could easily recognize and understand the meaning of German modality construction. The students are non-native speakers who surely have many constraints and difficulties in studying German modality. As has been mentioned above, modality meaning is of two types, namely, objective meaning and subjective meaning. The objective meaning is the meaning found in the grammatical or lexical element and the subjective meaning is the meaning found outside the grammatical or lexical meaning.

With the above as background, the problem in the research concerned here could be formulated as follows.

1. What are the objective and subjective modal verb constructions like in German sentences?

2. What are the objective and subjective modal verb meanings in German sentences?

3. What are the Indonesian equivalents of objective and subjective modal verbs in German sentences?

The research had the objective of describing

1. objective and subjective modal verb constructions in German sentences,

2. objective and subjective modal verb meanings in German sentences, and

3. the Indonesian equivalents of objective and subjectivemodalverbsinGermansentences.

Results of the research would be beneficial for students in the process of learning German in Semester 4 because the Modalverb 'modal verb' material of objektive und subjektive Bedeutung 'objective and subjective meaning' is found in the lesson book Studio-D B1. Hopefully, the students could understand well the modal verb constructions with objective and subjective meanings in German sentences and the Indonesian equivalents of the modal verbs.

\section{LITERATURE REVIEW}

Modality construction in German has two possible meaning types, namely, objective meaning and subjective meaning. The objective meaning is the meaning as contained in lexical items while the subjective meaning is the meaning containing elements external to lexical items (Eisenberg, 2004: 277). The lexical items for German modality which are commonly used to express objective meaning are in the form of, among others, the words equivalent to can, may, shall, will, must, and so on. It is related to what is categorized as looseness (or flexibility or resilience) of lexical items for modality in the German language enabling their meaning to be expressed with other words or even other constructions. When lexical items are not in that way loose in nature, it is because of the occurrence of modality function that is meaningful outside the lexical context. The meaning could then be categorized as subjective meaning. The subjective meaning is caused by the occurrence of a spreading of meaning into areas outside the attached lexical context so that the meaning could be of uncertainty, doubtfulness, vagueness, and so on. The subjective meaning could somehow then also be said to be of possibility, ability, and permission.

Objective meaning could be interpreted as loose or flexible or resilient in nature because a lexical form could mean in accordance with the meaning found in each item concerned, as in the following sentence.

(4) Es ist schade, dass er uns nicht besuchen kann (Dreyer \& Schmitt, 2012: 109).

'It is quite a pity that he cannot visit'.

The meaning of the modality found in the German sentence is objective in nature because the meaning of 'cannot visit' is the one found in the combined lexical items nicht besuchen kann.

It is different with the following sentence, which has subjective meaning.

(5) Der Kommissar muss sich in diesem Fall geirrt haben (Dreyer \& Schmitt, 2012: 130).

'There is possibility that the commissioner has made a mistake'

It is caused by the presence of the meaning of doubtfulness or uncertainty outside the lexical context. Returning to the sentence example (4) Es ist schade, dass er uns nicht besuchen kann. it has a meaning in line with the grammatical or lexical meaning of the modality indicator kann, 
namely, 'can'. So nicht plus kann means 'cannot'. Further examination indicates that the meaning of 'can' in that sentence is objective in nature while the word use when subjective in nature could have the meaning of possibility, ability, and permission.

A modal verb in the German language, according to Engel (1991: 477) and Helbig/Buscha (2005: 32), does not stand as core or main verb but as helping verb explaining its core or main verb in a German sentence.

Kridalaksana (1994: 125) defines modality as a speaker's way to express an attitude towards a situation in an interpersonal communication or as the meaning of possibility, obligation, actuality, and so on expressed in a sentence. In the Indonesian language, the resilience of the modal verb können 'can' is expressed with words like barangkali 'may', harus 'must', akan 'will', and so on or with adverbial expressions like pada hakekatnya 'in essence', menurut hemat saya 'in my opinion', and so on. Alwi (1992: 5) agrees that modality is related more to the speaker's attitude towards what is stated in his or her utterance. However, the speaker's attitude still requires further explanation here. In his explanation, Alwi (Ibid., 36-252) distinguishes modality into four types, namely, (1) intentional modality covering wish, hope, invitation, and request; (2) epistemic modality covering possibility, predictability, obligation, and certainty; (3) deontic modality covering permission and command; and (4) dynamic modality, namely, ability.

Talking about the Indonesian language by using the term pendesak, which is formulated as verb modifier filling the predicate function, Sudaryanto (1983: 177) expresses that what is called modality indicator is identical with pendesak, considered equivalent to qualifier here and taking the possible forms of (1) interrogative qualifier (apalapakah as question indicator and $-k a h$, interrogative suffix, in verbal questions), (2) potential qualifier (dapat/bisa 'can', mampu 'be able to'), (3) desiderative qualifier (mau/ hendak 'will', perlu 'need', harus 'must'), (4) habitual qualifier (suka 'like', senang 'glad', biasa 'usually', takut 'afraid', mudah 'easy', sulit 'difficult'), and (5) dubitative qualifier (mungkin/ barangkali 'perhaps'). Attitude expression by a speaker could actually be said to be a speech act.
The speech act itself, as stated by Wijana (2010: 92), could be in the form of (1) assertive speech act, (2) performative speech act, (3) verdictive speech act, (4) expressive speech act, (5) directive speech act, (6) commisive speech act, and (7) phatic speech act. However, what are considerably used in sentences in relation with the modality meaning in sentences are verdictive, directive, and commisive speech acts.

According to Young, Lynne and Fitzgerald (2006: 217), the contextual and situational constructs consist of (1) field, (2) tenor, and (3) mode. The semantic aspects would be (1) ideational, (2) interpersonal, and (3) textual while the language choices would be (1) transitivity, (2) modality elements, and (3) theme, cohesion, and coherence.

Grundy (2008: 92) says that the meaning found in modality could be in the form of context, conventional meaning, cooperative princinple, defeasibility entailment, flout, generalized and particularized implicature, hedge, heuristic, historical pragmatics, implicature inference, maxim, principle, relevance, scalar implicature, truth value utterance token meaning, and utterance type meaning.

Dreyer and Schmitt (2012: 131) say that the modality with subjective meaning covers the following matters:

(1) meaning of uncertainty, as in the sentence

Die Burg muss von schwedischen Soldaten zerstört worden sein

'The castle must have been destroyed by Swedish soldiers'.

(2) meaning of doubtfulness, as in the sentence

Die Burg kann auch von rebellischen Bauern zerstört worden sein

'The castle could have been destroyed by rebellious farmers'.

(3) meaning of vagueness, as in the sentence

Die Burg mag durch ein Erdbeben zerstört worden sein 
'The castle might have been destroyed by an earthquake'.

(4) meaning of unclearness, as in the sentence

\section{Die Burg soll von Kaiser Heinrich erbaut worden sein}

'The castle should have been built by Emperor Heinrich'.

The meaning of uncertainty refers to the inaccuracy of the information given. It is caused by the occurrence of uncertainty in the speaker. The meaning of doubtfulness refers to the instance that the truthfulness of the information given by the speaker is still doubted. The meaning of vagueness refers to a possibility but its being true or not is still not certain yet. The meaning of unclearness refers to an assumption and whether it is true or not is still not clear yet. Further, Buscha and Zoch (2005: 116) says that vor allem wie seine Einschätzung der Realität dieser Aussage ist 'especially as his assessment of the reality of this statement is' (Vermutung, fremde Behauptung u.Ä.).

The most important meaning in objective modality is of will/intention, which covers (1) permission/prohibition, (2) sake or interest/ demand, and (3) possibility. With the objective modal verb as basis, the subjective modal verb could be determined by way of observing the relation between the subject role and the infinitive verb to see whether the subject is directly related to the infinitive plus modal verb or the subject is related to the infinite verb only. The relation between the subject and the infinitive verb is linked to the modal verb.

\section{METHOD}

The data object of the research was the lingual unit with modality construction having objective and subjective meaning in both phrase and sentence form in German. The data subject was the modal verb in German sentences.

The data source in the research consisted of all the German phrases and sentences categorized as containing modal verbs in the magazine named NADI (short for Nachrichten für Alumni über Deutschland und Indonesien 'News for Alumni on
Germany and Indonesia') bilingually published as Indonesisch - Deutsch 'Indonesian and German' by DAAD (short for Deutscher Akademischer Austauschdienst 'German Academic Exchange Office/Agency'). The magazine is usually published twice a year in April and October. The reason for choosing the magazine is that in each issue two languages are used, German and Indonesian. The persons in its editorial board come from two countries, namely, Germany and Indonesia. Therefore, it could be said that the German and Indonesian languages used in the magazine are already standard in accordance with the rules of the languages.

As for the issues used as data source of the research, they are identified as follows.

1. Majalah NADI Indonesia Deutsch Edisi Tahun 2012 (Oktober),

2. Majalah NADI Indonesia Deutsch Edisi Tahun 2013 (April), and

3. Majalah NADI Indonesia Deutsch Edisi Tahun 2013 (Oktober).

The data were collected by using the technique called read and note (Sudaryanto, 1996). The technique was applied by means of carefully reading the whole data source. Then the whole data corpus collected in the form of modality with objective and subjective meaning was recorded by meticulously writing the whole data down. The recording was done on data cards to ease the categorization of the data corpus. It was necessary for the following material analysis in order to find modality meaning equivalents between the German and Indonesian languages (Wray, Trott, and Bloomer, 2003: 153).

The data analysis used two methods, namely, those here called metode padan 'correspondential method' and metode agih 'distributional method' (Sudaryanto, 1993). Metode padan was used with what is here called teknik pilah referensial 'referential sorting technique'. The technique uses reference to modality construction with objective and subjective meaning as determiner. Metode agih was used with teknik bagi unsur 'element distribution technique' and teknik baca markah 'marker reading technique'. Teknik bagi unsur was used to know the constituents forming the modality construction with objective and subjective meaning. Teknik baca markah was 
used to determine markers of the construction and function of modality with objective and subjective meaning in German sentence units and their Indonesian equivalents.

The validity of the data collected was tested by requesting two experts, namely, Prof. Dr. Pratomo Widodo, M.Pd. and a native speaker from Germany named Larissa Erna Pangarestian Harahap, M.A., to help validate the research data corpus. Then verification of the research data and research results was done by peer reviewers from the linguistics group in the Study Program of German Language Education, Faculty of Languages and Arts, State University of Yogyakarta, to know whether the research data were already reliable and the research results were already accountable in their authenticity.

\section{FINDINGS AND DISCUSSIONS}

Results of the research indicate that there are 192 times of modal verb use in the three issues (namely, the issues of October 2012, April 2013, and October 2013) of the NADI magazine.

The reason is that the modal verb können is used 107 times, the modal verb dürfen is used eight times, the modal verb sollen is used twentyseven times, the modal verb wollen is used only three times, the modal verb müssen is used thirtyone times, and the modal verb möchten is used sixteen times. These modal verbs in a diversity of their variant forms, namely, können, kann, kannst, konnte, darf, dürfte, dürfen, will, wollte, wollen, muss, musst, müssen, möchte, möchtest, and möchten, are used in a total of 192 times.

Their occurrence is related to the objective and subjective orientation of the semantic meaning. The modal verb used with the greatest number of times is können, its frequency of use being 107 . It could be interpreted to mean that the modal verb können has considerable influence on the expression of German sentence meaning in the NADI magazine with that modal verb, when translated into Indonesian, becoming the words bisa/dapat 'can', mampu 'be able to', and mungkin 'maybe'. It clearly proves that können is a modal verb which is dominant in use in the NADI magazine. It is caused by the beneficialness in the use of the modal verb können with the highest frequency of use that it has. It could be interpreted that the higher the frequency of use of a modal verb in German sentences in the NADI magazine, the more important the modal verb. Conversely, it could also be interpreted that the lower the frequency of use of a modal verb in the German sentences, the less important the use of the modal verb in the sentences.

Therefore, the research also counted the frequency of modal verb use in German sentences in the NADI magazine. Meanwhile, the focus of the study was on the objective and subjective modal verb constructions in sentences, the objective and subjective modal verb meanings, and the equivalents related to them in German and Indonesian sentences.

The use of modal verbs in sentences could be viewed from two points, namely, first, that of modal verbs with subjective meaning and, second, that of modal verbs with objective meaning. The objective meaning that a modal verb has is the meaning as contained in it as lexical item while the subjective meaning that a modal verb has is the meaning containing an element external to it as lexical item (Eisenberg, 2004: 277). The lexical items expressing modality in the German language which are usually used to express objective meaning are, among others, the words equivalent to can, may, shall, will, must, and so on.

It is caused by what is categorized as the looseness or flexibility or resilience of modality lexical items in the German language. When the lexical items are not that loose in nature, it is caused by the presence of modality function having meaning outside the lexical context. The meaning could then be categorized into subjective meaning. The subjective meaning is caused by the spreading of meaning out of the attached lexical context so that the meaning could be of uncertainty, doubtfulness, vagueness, and so on. The subjective meaning could also be said to be of possibility, ability, and permission. The objective meaning could be interpreted as being loose or flexible or resilient in nature because the lexical item could mean consistently in line with the meaning originally associated with it regardless of the sentence it is in.

The focus of the study was on objective and subjective modal verb constructions in German sentences, objective and subjective modal verb 
meanings in such sentences, and equivalents related to them in German and Indonesian sentences.

\section{OBJECTIVE AND SUBJECTIVE MODAL VERB CONSTRUCTIONS IN GERMAN SENTENCES}

The objective and subjective modal verb constructions in sentences could be seen in the exposition of research data as follows.

\section{a. Objective Modal Verb Construction}

As said by Eisenberg (2004: 277), a modal verb with objective meaning is that with meaning which is like that contained in any lexical item that it has while a modal verb with subjective meaning is that with meaning which is external to any lexical item that it has.

The following is some data exposition, each time consisting of the German and Indonesian versions in the data source.

(1) Unsere deutsch-indonesische Zusammenarbeit muss diesen veranderten Standortbeschreibung Rechnung tragen (NADI 2012: 7).

Kerja sama antara Jerman dan Indonesia harus memperhitungkan penggambaran lokasi yang berubah ini (NADI 2012: 6).

'Our German-Indonesian collaboration must take into account this modified site description'

(2) Das internationale Potential, das diese mobilen jungen Wissenschaftler mitbringen, sollte die Perspektive der Heimatuniversitäten ebenso erweitern wie die ihrer Gastuniversitäten (NADI 2012: 7).

Potensi internasional, yang membawa para ilmuan muda yang bersifat mobil ini, harus memperluas perspektif keduanya, baik universitas pengirim maupun universitas tujuan (NADI 2012: 6).

'The international potential which these mobile young scientists bring should broaden the perspective of both their native universities and their host universities'
(3) ..., sich auch nach der Ausbildung stetig weiter entwickeln zu können und ihre internationalen Netwerken zu pflegen (NADI 2012: 7).

..., setelah masa pendidikannya untuk terus menerus dapat mengembangkan dirinya dan membina jejaring internasionalnya demi kepentingan perbaikan kualitas (NADI 2012: $6)$.

'..., even after their education to constantly be able to develop themselves and their international networks for the sake of quality improvement'

(4) ..., dann wollte Herr Gulba nicht mitkommen (NADI 2012: 25).

..., maka Herr Gulba tidak mau ikut serta (NADI 2012: 24).

'..., then Mr. Gulba would not come along'

(5) In der Tradition des so genannten sanggar möchte das IVAA seine Arbeit in einen gemeinschaftlichen Kontext setzen... (NADI Anfang 2013: 33).

Dalam tradisi yang disebut sanggar ini IVAA ingin menempatkan tugas mereka di dalam sebuah konteks (NADI Anfang 2013: 32).

'In the tradition of the so-called sanggar IVAA would like to put his work in a community context'

(6) ..., hätten sich die Väter und Mütter der Entscheidung kaum vorstellen können, ... (NADI 2012: 7).

..., mungkin para pendiri yang mengambil keputusan tersebut dapat membayangkan, ... (NADI 2012: 6).

'..., had the fathers and mothers been hardly able to imagine the decision themselves'

The German modal verb construction in Data 
(1) is muss + tragen, that in Data (2) is sollte + erweitern, that in Data (3) is ertwicklen zu können, that in Data (4) is wollte + mitkommen, and that in Data (5) is möchte + setzen. Based on the modal verb construction that ordinarily refers to the rule implied by Subjek+Modalverb+Infinitiv, it could be said that data (1) up to (5) already meet the requirement of the sentences having the construction fitting the rule of Subjek+Modalverb+Infinitiv. More than that, there are even some attributes in the form of Adjektivdeklination 'adjective declination', Lokalangabe 'local indication', and Ergänzung 'complement'. It is seen that in the German sentence of Data (1), namely, Unsere deutsch-indonesische Zusammenarbeit muss diesen veranderten Standortbeschreibung Rechnung tragen., Unsere deutsch-indonesische Zusammenarbeit 'Our German-Indonesian cooperation' is Subjek, muss 'must' is Modalverb, diesen veranderten Standortbeschreibung 'this changed location description' is Akkusativobjek, and Rechnung tragen 'take into account' is Infinitiv. Therefore, it could be said that the construction in Data (1) already meets the criteria for a German sentence categorized as Modalsatz 'modal expression'.

As for any effort to know whether Data (1) up to (5) present sentences with subjective or objective modal verb construction, it needs to be made with a study on views from some experts as basis. Engel (1991: 477) and Helbig/Buscha (2005: 32), among others, say that modal verbs in German sentences do not stand as main verbs but as helping (or auxiliary) verbs explaining the main verbs. According to Young (2006: 217), the contextual and situational constructs consist of (1) field, (2) tenor, and (3) mode. The semantic aspect would be (1) ideational, (2) interpersonal, and (3) textual in type while the language choice would be characterized by (1) transitivity, (2) modality element, and (3) theme, cohesion, and coherence.

Based on the above diagram, it could be said that the objective modal verb could be determined by the existence of a strong relation between Modalverb and Infinitiv. Pada modal subjektif, the relation between Subjek and Infinitiv is stronger than that between Modalverb and Infinitiv. Jika dicermati berdasarkan konstruksi hubungan antara Subjekt-Infinitiv +Modalverb dan konstruksi
Subjekt+Infinitiv-Modalverb, maka data (1), (2), (3), (4), dan (5) berkonstruksi sebagai kalimat yang mengandung unsur objektives Modalverb.

As for Data (6), namely, ..., hätten sich die Väter und Mütter der Entscheidung kaum vorstellen können, ... (NADI, 2012: 7) '..., mungkin para pendiri yang mengambil keputusan tersebut dapat membayangkan, ... '(NADI 2012: 6), it could be explained here that die Väter und Mütter is Subjekt, followed by the modal verb können and the main verb vorstellen. An analysis on the semantic features that the sentence in Data (6) has would show the meaning of possibility in the modal verb.

The relation between Subjekt and Infinitiv appears to be more dominant in comparison with that between Subjekt and Modalverb. It could be interpreted as an instance of Modalverb with meaning outside its lexical context. The usual meaning of the modal verb können is 'can' (or of ability). However, in Data (6) there is an added meaning of possibility, as implied by the word mungkin 'perhaps' in the Indonesian translation of the German sentence in the NADI magazine. The Indonesian version includes the following: ... mungkin para pendiri mengambil keputusan ... .

Therefore, it could be said that the modal verb construction in Data (6) is of subjektive Modalverb because the meaning of the modal verb concerned is outside the lexical context.

\section{OBJECTIVE AND SUBJECTIVE MODAL} VERB MEANINGS IN GERMAN SENTENCES As for the meaning contained in sentences with objective and subjective modal verb construction as basis, it could be examined in the following data. (7) ..., hätten sich die Väter und Mütter der Entscheidung kaum vorstellen können, ... (NADI Oktober 2012: 7).

..., mungkin para pendiri yang mengambil keputusan tersebut dapat membayangkan, ... (NADI Oktober 2012: 6).

'..., had the fathers and mothers been hardly able to imagine the decision themselves'

(8) Da, wo die internationalen Erfahrungen und Perspektiven, die angesichts des rasanten Tempos neuer Informationstechnologien 
und mobiler Wissenschaftler und Studenten gewonnen werden konnten, ... ' (NADI Oktober 2012: 7).

Di sana, dimana pengalaman dan perspektiv internasional dapat diraih, berkat kemajuan teknologi informasi yang sangat pesat dan para ilmuan dan mahasiswa yang bersifat mobil ... (NADI Oktober 2012: 6).

'There, where the international experiences and perspectives, the face of the rapid pace of new information technologies and mobile researchers and students could be won ...'

(9) Auch die fünfte Auflage der mittlerweile fest etablierten European Higher Education Fair konnte im Jahr 2013 in zwei indonesischen Städten überzeugen (NADI Oktober 2013: 11).

Pameran pendidikan tinggi Eropa, yang pada tahun 2013 ini adalah yang kelimakalinya diadakan, telah mampu meyakinkan dua kota besar di Indonesia (NADI Oktober 2013: $10)$.

'Also, the fifth edition of the now firmly established European higher education fair could convince in the year 2013 in two Indonesian cities'

Data (7) consists of the partial German sentence as follows: ..., hätten sich die Väter und Mütter der Entscheidung kaum vorstellen können, ... (NADI Oktober 2012: 7) and its Indonesian translation as follows: ..., mungkin para pendiri yang mengambil keputusan tersebut dapat membayangkan, ... (NADI Oktober 2012: $6)$. It clearly indicates the role of semantics in interpreting the lexical items. The modality construction können + vorstellen is translated by using the word mungkin 'may, perhaps'. It means that the meaning of the modal verb können, which should be of ability, becomes that of possibility. The meaning of mungkin is outside the lexical meaning of können. Therefore, it could be said that the meaning in Data (6/7) is subjektive Bedeutung 'subjective meaning' from the speaker who desires the presence of meaning from outside the lexical item.

It is in line with what is previously said by Helbig/Buscha (2005: 116), namely, that vor allem wie seine Einschätzung der Realität dieser Aussage ist (Vermutung, (fremde Behauptung u.Ä.). The most important meaning of the objective modality is of will/intention, which covers (1) permission/ refusal/prohibition, (2) interest/demand, and (3) possibility. Data (6/7) is already in accordance with the third meaning based on Helbig/Buscha.

\section{OBJECTIVE AND SUBJECTIVE MODAL VERB EQUIVALENTS IN GERMAN AND INDONESIAN SENTENCES}

Objective and subjective modal verb equivalents in sentences could be seen in the data presented as follows.

(10) In diesem Zusammenhang möchte ich auf die von Bundeskanzlerin Dr. Angela Merkel und dem indonesischen Präsidenten Yudhoyono verabschiedete "Jakarta Declaration" hinweisen, deren Ziel es ist Globalisierungs prozesse gemeinsam verantwortungsvoll zu gestalten... (NADI, April 2013: 5).

Sehubungan dengan itu saya ingin mengingatkan akan "Deklarasi Jakarta", yang telah diresmikan oleh Kanselir Republik Federal Jerman Dr. Angela Merkel dan Presiden Republik Indonesia Yudhoyono, yang tujuannya adalah menciptakan proses globalisasi secara bersama-sama... (NADI, April 2013: 4).

'In this connection, I would like to point out the "Jakarta Declaration" that the German Chancellor Dr. Angela Merkel and the Indonesian President Yudhoyono adopted, whose aim is responsibly making globalization processes together'

The modal verb möchte in the German sentence in Data (10) would be considered equivalent to the Indonesian word ingin. The two words could be said to have the same meaning. The German and Indonesian sentences semantically have sameness in meaningmem. Both are also sentences indicating modality. Therefore, learners of German would 
not have difficulties in understanding the German sentence.

(11) Die Einwohner der Stadt müssen zudem unter Verkehrsproblemen und damit einhergehend einer hohen Luftverschmutzung leiden (NADI, April 2013: 13).

\section{Penduduk Jakarta harus menderita akibat} kemacetan lalu lintas dan juga polusi udara yang tinggi (NADI, April 2013: 12).

'The inhabitants of the city must have traffic problems and associated suffering from air pollution'

In the sentences of Data (11), the German modal verb müssen has sameness in meaning with the Indonesian word harus. Both are also indicators of modality in the sentences. The difference is only in the sentence construction. Semantically, however, both have sameness and equivalence in meaning.

(12) So beschloss auch UN-Habitat (Wohn- und Siedlungsprogramm der Vereinten Nationen) auf ihrer letzen Konferernz in Istambul in der Abschlussagenda, dass Selbstorganisation die Grundlage von Städten darstellt und daher locale Organisationen gefördert werden sollten (NADI, April 2013: 14).

Maka UN-Habitat (program tempat tinggal dan pemukiman dari salah satu lembaga PBB) pada konferensi terakhir mereka di Istambul menyimpulkan dalam agenda tertutup mereka, bahwa organisasi mandiri harus didukung (NADI, April 2013: 14).

'So UN-Habitat (housing and settlement program of the United Nations) also decided in the final agenda of their last conference in Istanbul that self- organization represents the foundation of cities and therefore local organisations should be encouraged'

Structurally, the two sentence versions of Data (12) indeed have a difference. Semantically, however, both have sameness in meaning. The German modal verb sollten comes from the word sollen meaning 'must' or 'ought'. The construction is usually used in indirect speech. However, when compared, the German and Indonesian sentences in Data (12) have sameness in meaning.

(13) Vieles von dem, was ich in Deutschland gelernt habe, kann ich meiner Arbeit gebrauchen, nicht nur in Indonesien sondern auch in den USA (NADI, April 2013: 19).

Banyak sekali yang saya dapat dari Jerman yang digunakan dalam pekerjaan saya, tidak hanya di Indonesia tapi juga di USA (NADI, April 2013: 18).

'I can use much of what I learned in Germany in my work, not just in Indonesia but also in the United States'

In Data (13), the German sentence expresses modality but it does not automatically result in the other sentence, the Indonesian version, also expressing modality in the same way. The reason is that the Indonesian word dapat turns out to be not the direct translation of the German word können. In the German sentence, the modal verb können works together with the verb gebrauchen. The resulting verb phrase means 'can be used'. However, in the Indonesian version appears the translation saya dapat dari Jerman. It indicates that there is no sameness in meaning. Semantically, the two sentences contain modality. However, in its actualization, the Indonesian sentence is not equivalent with the German one. Therefore, it could be concluded that the modal verb können would be considered equivalent to the zero modal word in the Indonesian sentence.

(14) Wir dürfen jetzt in dieser Situation und in dem Zustand, in em sich die Natur, unsere Kinder und die Umwelt befinden, sowie die von uns vernächlassigten mensclichen Werte, nicht aufgeben (NADI, April 2013: 29).

Hal ini yang saya yakini harus terus disampaikan, jangan menyerah di tengahtengah situasi dan kondisi alam, anak2 dan lingkungan serta nilai2 kemanusiaan yang sedang tersisihkan oleh kealfaan kita, pembiarankita...(NADI,Oktober2013:28).

'We must now not give up in this situation 
and in this state, this condition of nature, our children, and the environment, as well as the our oversight of humane values'

The German sentence in Data (14) uses the modal verb dürfen. This modal verb has the meaning of permission. However, the actualization of its expression in the Indonesian language is the word harus. It indicates that though the two sentences have sameness in modality meaning, the German modal verb dürfen is translated into the Indonesian word harus. Therefore, it could be said that the two sentences possess word equivalents that are almost the same depending on the sentence contexts. In certain instances, the word dürfen could be used to express the meaning of, respectively, permission, may, and for. The Indonesian word harus is a modal verb and it is used to express something obligatory or compulsory in nature. What is special is that if the sentences in Data (14) are semantically compared, they would still be seen to possess sameness and equivalence in meaning.

\section{CONCLUSIONS}

Based on the above discussion, it could be concluded as follows.

1. Modal verb construction in the German language is of two types, namely, that with objective meaning and that with subjective meaning. In German, the construction of modality with objective meaning is $S-\operatorname{Inf}+$ Modalverb and that with subjective meaning is $S+$ Inf-Modalverb.

2. Objective modal verb meaning is loose (or flexible or resilient) in nature because the modality lexical item could express the utterance content while subjective modal verb meaning is outside the lexical item because it is influenced by the subjectivity of the speaker's intention. In principle, the modality is subjective when based on the speaker's intention. Thus, in German sentences, the use of subjective meaning is more dominant compared to the use of objective meaning.

3. As for the Indonesian equivalents of objective and subjective modal verbs in the German sentences put under analysis, it is found that the modal verb können appears 107 times with dapat, bisa, ada, menjadi, berhasil, mampu, meraih, terdiri, sungguh, and makna zero 'zero meaning' as its equivalents, the modal verb dürfen appears eight times with dapat, boleh, dan makna zero as its equivalents, the modal verb sollen appears twenty-seven times with harus, akan, bisa, seharusnya, perlu, and makna zero as its equivalents, the modal verb wollen appears three times with ingin, terus terang, and makna zero as its equivalents, the modal verb müssen appears thirty-one times with harus, dapat, bisa, and makna zero as its equivalents, and the modal verb möchten appears sixteen times with ingin, berminat, perlu, and makna zero as its equivalents.

Based on the research results as above, suggestions could be given to other prospective researchers interested in conducting research on modal verb construction in German sentences. German modal verbs have two possible types of meaning, namely, objetive meaning and subjective meaning.

The subjective meaning appears when the speaker wishes to express an attitude associated with a meaning which is external to the lexical context being used. It is related to the semantic meaning that is found in the utterance context and refers to other meaning covering (1) assumptive meaning as in mungkin, tidak tahu, and tidak jelas; and (2) ordinary meaning used to express a message delivered by the speaker to a hearer which contains something outside the grammatical or lexical context. In other words, the message contains meaning external to modality and highly subjective in nature, depending on the speaker's intention and purpose in expressing what is in his or her mind.

Modality with objective and subjective meaning is found in all languages, including the Indonesian language. Indonesian words like mau, akan, hendak, harus, and boleh indicate modality with objective meaning while those with subjective meaning could be mungkin, kayaknya, acapkali, and barangkali. In using the Indonesian language, the expression of the speaker's attitude is ordinarily actualized in accordance with explicit word meaning. 


\section{REFERENCES}

Alwi, Hasan (1997). Modalitas dalam Bahasa Indonesia. Yogyakarta: Kanisius Press.

Buscha, Joachim \& Irene Zoch (2005). Der Infinitiv. Zur Theorie und Praxis des Deutschunterrichts fiir Ausländer. Leipzig: Langenscheidt Verlag Enzyklopädie.

Dreyer, Hilke und Schmitt, Richard (2012). Lehrund Übungsbuch der deutschen Grammatik. Neuberartung. Die Gelbe aktuell. Ismaning, Deutschland: Heber Verlag.

Engel, Ulrich (1991). Deutsche Grammatik. Heidelberg : Julius Groos Verlag.

Eisenberg, Peter (2004). Grundri $\beta$ der deutschen Grammatik. Stuttgart: Verlag J.B. Metzler.

Grundy, Peter (2008). Doing Pragmatics. London: HolderEducation, PartofHachette LivreUK.

Helbig, Gerhard and Buscha, Joachim 2005. Deutsche grammatik. Ein Handbuch für den Ausländerunterricht. Berlin und München: Langenscheidt KG.

Kridalaksana, Harimurti (1994). Kamus Linguistik. Jakarta: Gramedia.

Sudaryanto (1993). Metode dan Aneka Teknik Analisis Bahasa. Pengantar Penelitian Wahana Kebudayaan secara Linguistik. Yogyakarta: Duta Wacana University Press.
(1996). Linguistik. Identitasnya, Cara Penanganan Objeknya, dan Hasil Kajiannya. Yogyakarta: Duta Wacana University Press.

(1998). Predikat-Objek dalam Bahasa Indonesia, Keselarasan Pola Umum. J akarta: Penerbit Djambatan.

(2015). Verhaar, J.W.M. (2001). Pengantar Linguistik. Yogyakarta: Gadjah Mada University Press.

2006. Asas-asas Linguistik Umum. Yogyakarta.GadjahMadaUniversityPress.

Wijana, I Dewa Putu (2010). Semantik Bahasa Indonesia. Program Sudi S2 Linguistik FIB Universitas Gadjah Mada, Yogyakarta bekerjasama dengan Pustaka Pelajar.

Wray, Alison; Trott, Kate; Bloomer, Aileen (2009). Linguistics: A Practical Guide to Researching Language. Great Britain: Bookcraft Bath.

Young, Lynne and Fitzgerald, Brigid (2006). The Power of Languge. London: Library of Congress Cataloge in Publication Data. 